\title{
EFFECT OF SUCCESSION PLANNING ON ORGANIZATIONAL GROWTH
}

\author{
Ammad Zafar* \\ Ghazal Khawaja Hummayun Akhta***
}

\begin{abstract}
In today's modern world, globalization has increased competition among the organizations. In order to meet competition every organization require high skilled work force. Organizations are becoming more dependent on skilled work force. Increase in competition has also been increasing the stress on employees that is causing high turnover in organization. Increase in employee turnover and unavailability of skilled work force has an indispensable question on the future growth of organizations. Every organization has two ways to tackle this situation either to hire person for the vacant key position from outside or to promote employee within the organization. The Study aims to analyze the impact of succession planning on organizational growth and association of gender variation with growth of organization. A survey of 300 persons doing an official task under the management, were interviewed through questionnaire based on five points Likert scale and developed through pilot study. Convenience sampling was used to draw the sample including 150 males and 150 females. Logistic regression was used to calculate impact of succession planning on organizational growth. Result of the study reveals effective succession plan can help the organization to meet desire objectives. It has significant positive impact of 2.5 times on growth of organization by increasing number employees through accurate hiring and by retaining key personnel on key position. Study also concludes, gender variation has no association with growth of organization.
\end{abstract}

Keywords: Succession planning; size of organization; employee retention; organizational growth

\section{Introduction}

The present world is organized by rapid globalization which is reinforcing the strength of a world entrepreneur financial framework. Globalization is overriding the power of the country state with trans-national, or potentially worldwide organizations and associations. With expanding globalization, there have been gigantic and extensive changes in worldwide associations. These progressions are the consequence of worldwide serious pressure exert by ventures working in the worldwide commercial center. These progressions have introduced a circumstance whereby there are gainers and washouts in the worldwide commercial center. In this manner, while a few associations are improving, making some swell memories; overcoming ages (e.g. Kodak); overcoming serious rivalry (e.g. Microsoft); and at last going worldwide (e.g.

This work is Licensed under a Creative Commons Attribution-Non-Commercial 4.0 International License (c) (1) ()

\footnotetext{
* Ammad Zafar, Ph.D. Scholar, Department of Public Administration, University of Karachi

** Ghazal Khawaja Hummayun Akhtar Ph.D. Assistant Professor, Department of Public Administration,

University of Karachi
} 
Unilever), others are thinking that it's hard to exist and endure the worldwide rivalry and antagonistic worldwide financial fortunes (e.g. Opel). The study suggests that the performance of associations is impliedly connected with this contemporary worldwide request ${ }^{1}$.

The problem of this examination is grown from the way that the approach and beginning of the $21^{\text {st }}$ century got phenomenal and to a great extent unexpected change the worldwide viewpoint, with the rise of worldwide financial frameworks. This change, an embodiment of financial change, is showed in the adjustment of the monetary structures, associations, methods for creation, and dispersion of merchandise and enterprises ${ }^{2}$. To its advocates, globalization is acceptable because it is an impression of progress, improvement, headway and development. This is on the grounds that, through unhindered commerce and communications among countries, globalization pushes economies towards more elevated levels of performance and growth in yield ${ }^{3}$.

Organizational growth has been continuingly a significant question in corporate world since decades. Many studies have been conducted about to find factors that contribute organizational growth. In the modern world it is become an indispensable question that every organization must address. Many researchers have defined organizational growth in terms of financial productivity, increase in number of employees, retention of existing skilled employees etc. The study has focused two important factors that are responsible for organizational growth such as increase in number of employees by placing right employee on the right job and retaining skilled staff. Many studies discussed an effective succession could provide a road map for future growth of organization. Succession planning is the process of identifying key areas and positions of organization. It establishes a system that guides organization for the achievement of its goals on time. According to studies of Rothwell 2008, succession planning has five key component such as identification of key areas and position of organization, identify competencies of individual require to fulfill a key position, enhance ability of existing staff as per future need of organization and evaluate the effectiveness of overall plan ${ }^{4,5}$. Study has revealed that an effective succession plan plays an important in the growth of organization by providing complete guidance about hiring of potential candidate for prospective leadership and retaining them for the desired time of organization ${ }^{6}$. Study has concluded an effective plan increases the growth of organization by many times. The growth of organization is independent of gender variation.

\footnotetext{
${ }^{1}$ Wokoma, Chiemela U., and E. B. J. Iheriohanma. "Interation Between Globalization and Organizational Performance in the Third World: Nigeria in Focus." Studies in Sociology of Science 1, no. 2 (2010): 72-80.

${ }^{2}$ Ayantayo, J. K. "Globalization: A New Ethnocentric Culture with Implications on African Social Values' inInternational." Review of Politics and Development: A Journal of the Department of Political Science and Sociology (2004).

${ }^{3}$ Iheriohanma, E. B. J. "The Challenges of Globalization and Poverty in the Third World: A Sociological Discourse of Nigeria's Situation." The Third World in Sociological Perspective. (Okigwe: FERPFASMEN, 2008): 241-255.

${ }^{4}$ Rothwell, William J. "Next Generation Talent Management." HRM Review 8, no. 10 (2008): 10-16.

${ }^{5}$ Day, David V. "Developing leadership talent." (SHRM Foundation, 2007).

${ }^{6}$ Lowan, Vongani, and Clever Chisoro. "The Impact of Succession Planning for Business Survival: A Case of Kwalita Business Consultants, Johannesburg (South Africa)." Kuwait Chapter of Arabian Journal of Business and Management Review 33, no. 3514 (2016): 1-28.
} 


\section{Problem Statement}

Studies have revealed only $73 \%$ of organizations reported growth and $27 \%$ of organizations reported no growth in last 3 years. Succession planning can be one of the leading factors that are responsible for rapid organizational growth. The study aims to analyze impact of succession planning on organizational growth.

\section{Research Questions}

- What is succession planning and what are components of effective succession planning?

- What is the meaning of organizational growth and how does it influence by succession planning?

\section{Research Objectives}

The study aims to develop an understanding about succession planning \& its component and organizational growth. It also analyzes relationship between succession planning and organizational growth.

\section{Literature Review}

Succession Planning is the process to fill vacancies as per requirement of organization. It provides framework for addition new staff. It also includes selection of right person for promotion on right job. It enhances the ability of existing staff and prepares them future need of organization. It provides individual growth to the employee. Studies reveals personal development of employees encourages them to stay more in organization ${ }^{7}$. An effective succession planning influences an employee in many ways. It includes planning about retention rate, employee compensation management, employee career development etc ${ }^{8}$. A succession plan guides to organization about all factors that are necessary to analyses for the continuity of business and for the future growth of employee in the organization. It is a series of many short plans ${ }^{9}$. It is usually designed to fulfill organizational mission with high quality skilled work force to achieve maximum productivity of organization ${ }^{10}$. Succession planning is an important part of human resource plan of organization. Dynamic human resource plan has many possible ways to forward from the challenges to organization ${ }^{11}$. An effective succession plan is an integral part of human resource plan at first stage it takes stock that means it identifies number of people required at initial level to align objective of organization with overall strategy of organization. It also identifies the minimum knowledge, skill, abilities and characteristics required to complete task. At second stage it forecast about

\footnotetext{
${ }^{7}$ Spurk, Daniel, and Andrea E. Abele. "Who Earns More and Why? A Multiple Mediation Model from Personality to Salary." Journal of Business and Psychology 26, no. 1 (2011): 87-103.

${ }^{8}$ Gray, Doug. "Succession Planning 101." Professional Safety 59, no. 3 (2014): 35.

${ }^{9}$ Checknita, J. "Develop Your Leaders of Tomorrow, Today: Succession Planning." Business in Calgary 21, no. 11 (2011): 9-10.

${ }^{10}$ Calareso, J. P. "Succession Planning: The Key to Ensuring Leadership: the key is that the process of leadership formation is not random and serendipitous, but rather intentional and well planned." Planning for Higher Education 41, no. 3 (2013): 27-34.

${ }^{11}$ Ivanchevich, John. Human Resource Management. (Irwin Professional Publication, 2007).
} 
productivity of organization ${ }^{12}$. An effective succession plan has two sub-phases, in the first phase it predicts about skills that must be carried by people and in second phase it predicts about number of people required for the achievement of organizational objective in future ${ }^{13}$. It is process of development of strategic plan for the need of organization. It provides a framework for the replacement of key employees in future ${ }^{14}$.

Succession planning depends on the data provided by talent audits, supply and demand forecast, and performance and potential review. In some enormous organizations wherein request and gracefully figures can be made precisely, exceptionally formalized succession planning forms dependent on such a management succession involved ${ }^{15}$.

Organizations nowadays are flourishing and falling flat, with their prosperity and disappointment being owed to an incredible number of elements. Organizational growth is significant when discussing the accomplishment of a business. A great deal goes into helping an organization growth and success. Without all the key position holders, a proportion can go nonfunctional in the organization. Their highest proximity is significant for a smooth working of a business. Since that may not be conceivable now and again, the ideal other option, for any business to guarantee the sheltered running of its business in all circumstances is to rehearse succession planning. It would not be right to state that fruitful organizational growth is just impractical without succession planning.

The idea of succession planning is an extremely basic yet essential one. In any organization, succession planning is the thing that balances out the growth of an organization for future perspectives ${ }^{16}$. Achievement planning can just be characterized as the procedure wherein various people that have been workers by the organization are checked, based on various factors, and picked to pass the mallet to for influential positions in the organization. Succession planning is likewise, on occasion, called management succession planning ${ }^{17}$. It is a procedure that is very essential for an organization to keep working with equivalent adequacy without key position holders. Succession planning can essentially be separated into two stages. First incorporates examining and choice, and the second, instructing. The two phases are significant, and the variables organized in each stage speak to the characteristics that you need to find in your key position holders.

Studies reveal, searching for people that organization feel hold the possibility to be a pioneer, organization should stop and characterize the characteristics that direct the said potential. Ideally, all characterized authority characteristics must be searched for. Notwithstanding, recollect that nobody individual can be relied upon to have all the necessary characteristics. If lacking, they could be guided and trained towards the characteristics that they need. However, there are in every case a few characteristics that

\footnotetext{
${ }^{12}$ Gallagher, Shaun. "Self Reference And Schizophrenia." Exploring The Self (2000): 203-239.

${ }^{13}$ Armstrong, Michael. "Strategic Human Resource Management-A Guide to Action 3rd Ed." (2006)

${ }^{14}$ Mathis, R., \& Jackson, J. Human Resource Management (11th ed.). (South-Western College Publication, 2006).

${ }^{15}$ Hirsh, Wendy. Succession Planning Demystified, (Brighton: Institute for Employment Studies, 2000).

${ }^{16}$ Berchelman, D. K. Succession Planning. The Journal for Quality and Participation, 28(3), (2005): 11-12.

${ }^{17}$ Leibman, Michael, Ruth A. Bruer, and Bill R. Maki. "Succession Management: The Next Generation of Succession Planning." People and Strategy 19, no. 3 (1996): 16.
} 
are inborn to any person. Such characteristics can't be educated or instructed. An individual must have them as it so happens. People who have the correct blend of such characteristics are picked. While thinking about these characteristics, additionally consider the bothersome characteristics that may eclipse all the ideal ones. It is significant for a person to have the correct blend of characteristics to be picked for succession planning. Study discussed an affective succession plan has positive influence on growth of organization.

Organizational growth is notably the combination of size of association for example number of individuals working in association, salary, benefit, or part of the overall industry in the business terminologies. Size of association is one of the pointers of organizational growth. It is become an important issue that every organization need to address on priority basis. It is apparent employee fulfillment is one driving variable to hold them. Studies uncovers employees which are getting increasingly possibility of improvement as far as bearer and individual are bound to be fulfills. Subsequently, association must maintain more concentration in learning of employee rather than their acquiring ${ }^{18}$. Size of association is impacted by two elements for example employee retention and acceptance of new employees. Association have low turnover rate or high employee retention are bound to grow their size with time. Individuals resemble to be a part of those associations which has better employee retention. Studies have uncovered the impact of succession plan that can increase the employee retention. A compelling succession plan can influence employee retention in different manners. It empowers employee to comprehend vision of association. It likewise explains employee about their bearer advancement. Studies additionally uncover legitimate succession planning of occupation impacts the degree of occupation fulfillment of employees. Studies uncovers fulfilled employees are bound to work with the association ${ }^{19}$.

\section{Hypotheses}

Study design is based on quantitative approach. It establishes hypotheses to achieve the objective of research. Hypotheses are based on dependent and independent variable. In this research organizational growth is dependent variable and succession planning is independent variable.

$\mathrm{H}_{10}$ : Variation in Gender has no association with organizational growth.

$\mathrm{H}_{1}$ : Variation in Gender has significant association with organizational growth.

$\mathrm{H}_{20}$ : Succession Planning has no association with organizational growth.

$\mathrm{H}_{2}$ : Succession Planning has significant association with organizational growth.

$\mathrm{H}_{30}$ : Succession planning has no significant impact on organizational growth.

$\mathrm{H}_{3}$ : Succession planning has significant impact on organizational growth.

\section{Methodology}

The study based on data collected from primary and secondary source. Primarily, a survey of 300 people working at managerial position was conducted in August 2019 to obtain their opinion about influence of formal plan / succession planning on

\footnotetext{
${ }^{18}$ Ackoff, Russell Lincoln. Ackoff's best: His Classic Writings on Management. (John Wiley \& Sons, 1999).

${ }^{19}$ Aziri, Brikend. "Job Satisfaction: A Literature Review." Management Research \& Practice 3, no. 4 (2011).
} 
organizational growth. A close ended questionnaire using five points Likert scale was developed based on questions about succession planning and its component. It also included questions about size of organization and employee retention which are components of organizational growth. A pilot study was done to collect the opinion of 15 researcher scholars belong to administrative sciences and also have working experience in management operations. Convenience sampling a type nonprobability sampling was used to draw sample for the study. It was ensured that $50 \%$ sample must be belonging to male respondent and 50\% to female of companies working under the domain of private sector. An electronic copy of questionnaire based on Google survey form was prepared for distribution to respondents. Research questionnaire was distributed to managerial personnel working in different organizational setting located in Karachi. The data collected through survey analyzed through multiple statistical tools to interpret trend of succession towards organizational growth. Logistic regression analysis was done to determine impact of independent variable that succession planning on dependent variable that is organizational growth. Secondarily, studies reviewed literature about relationship between succession planning and organizational growth. Various studies evident that formal plan / succession plan was an effective tool for sustainable growth of organization by adding quality workforce in organization also by retaining productive employee.

\section{Analysis and Discussion}

Analysis of data depicts 50\% respondents are male and 50\% are female (See Figure 1). Study reveals responses from both genders are similar. Change in Gender has no role in the achievement of organizational goal.

\section{Proportion of Respondent's Gender}

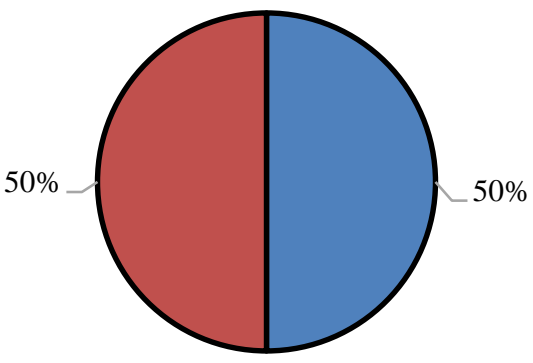

DMale QFemale

\section{Figure 1}




\section{Independent $t$ - test}

Independent $\mathrm{t}$ - test is a statistical tool to compare means two different populations ${ }^{20}$. Study attempts to verify reliability of responses respective to gender variation. Independent $\mathrm{t}$ - test analysis showed that responses from male has standard deviation near to standard deviation of responses collected from female gender (See Table - 1). In every successful organizational policy are maintained on the principles of equal employment opportunity. Many studies have revealed equal employment opportunity has a significant role in the success of organization. The organization has focused on equal employment opportunity to all employee are more likely to reduce the effect of gender variation on organizational growth.

Table - 1

\begin{tabular}{|l|c|c|c|c|}
\hline \multicolumn{5}{|c|}{ Group Statistics of Organizational Growth } \\
\hline Gender Respondent & N & Mean & Std. Deviation & Std. Error Mean \\
\hline Male & 150 & 0.693 & 0.463 & 0.038 \\
\hline Female & 150 & 0.767 & 0.424 & 0.035 \\
\hline
\end{tabular}

The t-test for equality of means has depicted there is no effect of variation in gender on organizational growth (See Table - 2). Study reveal there are factors which are responsible for change in growth of organization. The p-value for Equal variances assumed is greater than 0.05 . We failed to reject null hypothesis. Result of analysis depicted there is no association of gender variation with organizational growth. Either the male employee working in organization or female they are equally contributed towards organizational growth.

Table - 2

\begin{tabular}{|c|c|c|c|c|c|c|c|c|c|}
\hline \multicolumn{10}{|c|}{ Independent Samples Test for Organizational Growth } \\
\hline & \multicolumn{2}{|c|}{$\begin{array}{c}\text { Levene's Test for } \\
\text { Equality of } \\
\text { Variances }\end{array}$} & \multicolumn{7}{|c|}{ t-test for Equality of Means } \\
\hline & $\mathbf{F}$ & Sig. & $\mathrm{t}$ & df & $\begin{array}{c}\text { Sig. } \\
(2- \\
\text { tailed) }\end{array}$ & $\begin{array}{c}\text { Mean } \\
\text { Differen } \\
\text { ce }\end{array}$ & $\begin{array}{c}\text { Std. Error } \\
\text { Differenc } \\
\text { e }\end{array}$ & $\begin{array}{r}95 \% \\
\text { Inte } \\
\text { Di }\end{array}$ & $\begin{array}{l}\text { idence } \\
\text { of the } \\
\text { nce }\end{array}$ \\
\hline & & & & & & & & Lower & Upper \\
\hline $\begin{array}{c}\text { Equal } \\
\text { variances } \\
\text { assumed }\end{array}$ & 8.204 & 0.004 & -1.431 & 298 & 0.154 & -0.073 & 0.051 & -0.174 & 0.028 \\
\hline $\begin{array}{c}\text { Equal } \\
\text { variances } \\
\text { not assumed }\end{array}$ & & & -1.431 & 295.804 & 0.154 & -0.073 & 0.051 & -0.174 & 0.028 \\
\hline
\end{tabular}

${ }^{20}$ Kim, Tae Kyun. "T test As A Parametric Statistic." Korean Journal of Anesthesiology 68, no. 6 (2015): 540. 
Study has analyzed the responses about availability of a formal plan / succession plan in the organization to achieve organizational desire growth. $43 \%$ respondent agreed their organization has formal plan / succession plan to run operation of organization which can be responsible for organizational changes (See Figure - 2). Many studies have revealed that the organization that has a formal plan are more likely compete in market. Sustainability of organization always depends on effectivity of formal organizational plan. 57\% respondents choose their organization has no plan for organizational development. They are performing as per routine direction of supervisor or superior. Studies have revealed organization has no formal plan to achieve organizational goal are less likely to achieve their goal.

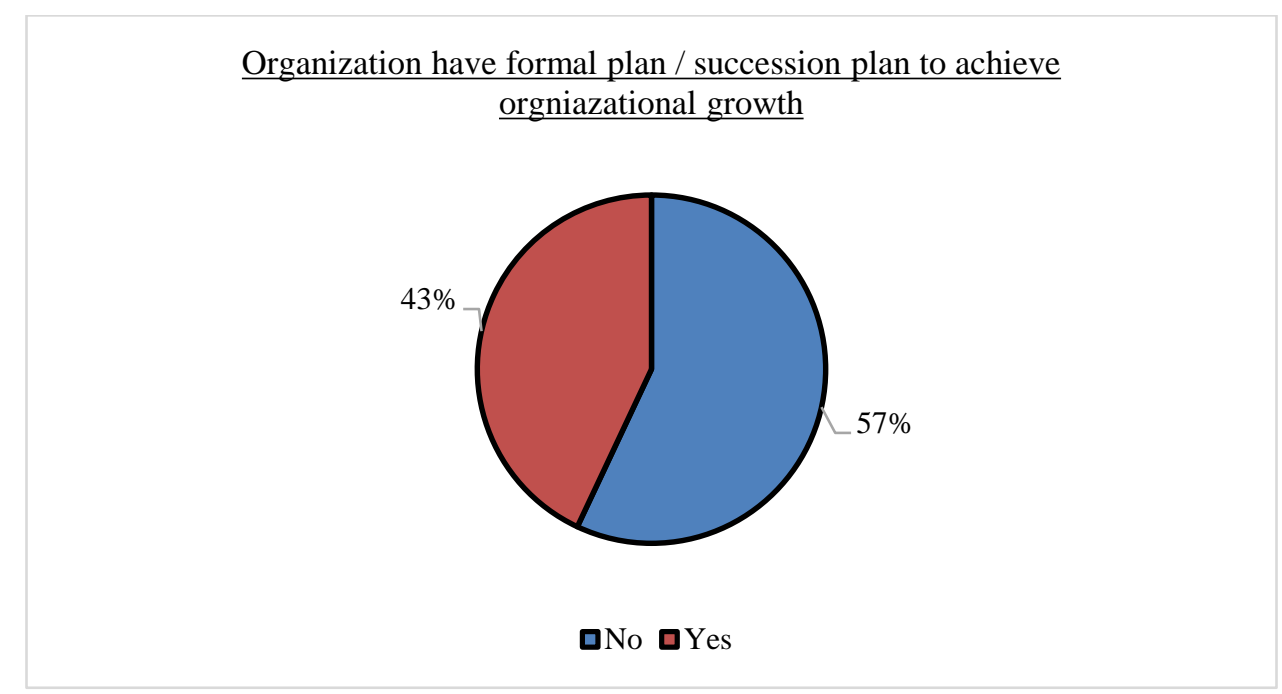

Figure - 2

$73 \%$ of respondents agreed their organization has growth in last three years (see Figure 3). They have agreed the size of organization has been increased in terms of number of employed staff. They agreed organization has hired right staff for right position in last three years. Organization also retains existing staff by treating them fairly. Zafar, Memon \& Khan 2018, discussed organization can enhance ability of employee by engaging them organization development plan that include training of employee for future assignment of the company. Studies have revealed organization that has better employment policy always have low employee turnover ${ }^{21}$.

${ }^{21}$ Zafar, A., Memon, A., \& Khan, M. N. Implication of HR Components on Employee Performance: A Comparative Analysis of Public and Private Sector Employees. Pakistan Administrative Review, 2(2), (2018): 223-232. 


\section{Proportion of organitzation having organizational growth in last three years}

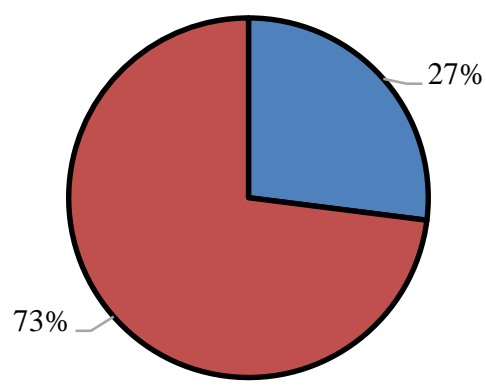

口No QYes

\section{Figure - 3}

Crosstab analysis of succession planning and organizational growth has depicted. Only $37 \%$ respondents agreed that formal plan /succession plan of organization is effective for the employee retention and hiring of right people for the right place ${ }^{22}$ (See Figure 4). Studies have revealed effective planning always has positive impact on organization growth. Effectiveness of plan can promote organizational growth many times.

\section{Proportion of organization having organizational growth due to} effective succesion plan

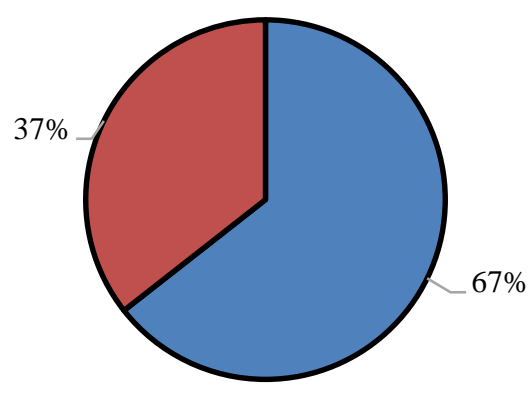

$\boldsymbol{\square}$ No $\boldsymbol{\square}$ Yes

Figure - 4

${ }^{22}$ Farthing, Kate. "Succession Planning: the Right People in the Right Positions at the Right Time." (2013): 175-176. 


\section{Chi-Square Tests}

Chi-square is used to measure association between variables ${ }^{23}$. Study has conducted chisquare analysis to verify association of succession planning and organizational growth. Analysis chi-square showed a significant association between independent variable and dependent variable (See

Table - 3). The p-value of chi-square test is less than 0.05 . We rejected the null hypothesis of no association between succession planning and organizational growth.

Table - 3

\begin{tabular}{|c|c|c|}
\hline \multicolumn{3}{|c|}{$\begin{array}{c}\text { Chi-Square Tests for association between succession planning and organizational } \\
\text { growth }\end{array}$} \\
\hline & df & Asymptotic Significance (2-sided) \\
\hline Pearson Chi-Square & 1 & 0.001 \\
\hline Continuity Correction & 1 & 0.001 \\
\hline Likelihood Ratio & 1 & 0.001 \\
\hline
\end{tabular}

\section{Logistic Regression Analysis} Model Summary

Binary logistic regression is effective tool to calculate the impact of independent variable on dependent variable ${ }^{24,25}$. Study has conducted logistic regression analysis to examine impact of succession planning of organizational growth. The model summary has showed variation caused affectivity of succession planning in the organization growth. Model explains that succession planning caused variation of $3.9 \%$ in organization growth (See Table - 4). Model summary depicts there are other variable which are also responsible for organizational growth.

Table - 4

\begin{tabular}{|c|c|c|c|}
\hline \multicolumn{4}{|c|}{ Logistic regression model summary for analysis of Succession Planning and } \\
Organizational Growth
\end{tabular}

${ }^{23}$ Ugoni, Antony, and Bruce F. Walker. "The Chi Square Test: An Introduction." COMSIG review 4, no. 3 (1995): 61.

${ }^{24}$ Iqbal, Sobia, and Ammad Zafar. "Determinant of Frequent Road Accidents in Megacities (A Case Study of Karachi)." Developing Country Studies 7, no. 3 (2017): 97-103.

25 Park, Hyeoun. "An Introduction to Logistic Regression: From Basic Concepts to Interpretation with Particular Attention to Nursing Domain." Journal of Korean Academy of Nursing 43, no. 2 (2013): 154164. 


\section{Analysis of Variable in Equation}

Logistic regression analysis showed a positive relationship between succession planning and organizational growth. The p-value for test is less 0.05 that indicated relationship between variable is statistically significant. Studies has rejected null hypothesis based on result. Regression analysis of variable showed succession planning has impact of 2.5 times on organizational growth (See Table - 5). As organizational implemented a success plan in effective manner the organizational growth will be higher by 2.5 times. Studies of Odhiambo, Njanja and Zakayo (2014) conclude, succession planning is necessary for Human resource operation such as recruitment, training and development, performance management, talent management and reward management. It provides integrated model for Human Resource operations. They also conclude, succession planning affects positively on internal business process and key component of organizational growth ${ }^{26}$.

Table - 5

\begin{tabular}{|c|c|c|c|c|c|c|}
\hline \multicolumn{7}{|c|}{$\begin{array}{l}\text { Logistic Regression variables in the equation for analysis of Succession Planning } \\
\text { and Organizational Growth }\end{array}$} \\
\hline & B & S.E. & Wald & df & Sig. & $\operatorname{Exp}(B)$ \\
\hline Succession Planning (1) & 0.907 & 0.266 & 11.644 & 1 & 0.001 & 2.50 \\
\hline Constant & 0.523 & 0.182 & 8.252 & 1 & 0.004 & 1.688 \\
\hline
\end{tabular}

\section{Conclusion}

Study has concluded that succession planning is not only the process of leadership development. It is also a leading factor for the organizational growth. An effective succession plan is the key for placement of right person on the right job. An effective succession plan not only identifies key areas of organization. It also identifies key position in the organization. An effective plan becomes responsible for organizational growth by fulfilling right person on key position and also by retaining them for long time. Study also concluded organization growth is independent of variation in gender but dependent on effectivity of formal plan / succession plan. It reveals an effective succession plan is associated with organizational growth and has a positive impact of 2.5 times. Increase in effectivity of succession plan cause more growth of organization in terms of increase in number of employed staff by hiring right staff on right place and retaining productive staff for the desired of organization.

\footnotetext{
${ }^{26}$ Odhiambo, J. O., L. Njanja, and C. Zakayo. Effects of Succession Planning Practices on Organization Performance among the Non-Governmental Organizations in Kenya. European Journal of Business Management 2, no. 1 (2014): 141-154.
} 


\section{Bibliography}

Ackoff, RL. Ackoff's Best: His Classic Writings on Management. New York: Londres: John Wiley and Sons, 1999.

Armstrong, Michael. Strategic Human Resource Management-A Guide to Action 3rd Ed. 2006.

Ayantayo, JK. Globalization: A New Ethnocentric Culture with Impact on African Social Values. International Review of Politics and Development 2, no. 2 (2004): 54-64.

AZIRI, Brikend. Job Satisfaction: A Literature Review. Management Research Practice 3, no. 4 (2011).

Berchelman, D Kevin. Succession Planning. The Journal for Quality and Participation 28 , no. 3 (2005).

Calareso, JP. Succession planning: the key to ensuring leadership: the key is that the process of leadership formation is not random and serendipitous, but rather intentional and well planned. Planning for Higher Education (Society for College and University Planning) 41, no. 3 (2013).

Checknita, J. Develop your leaders of tomorrow, today: Succession planning. Business in Calgary 21, no. 11 (2011).

Day, David V. Developing Leadership talent A guide to succession planning and Leadership Development. SHRM Foundation, 2014.

Farthing, Kate. Succession Planning: The Right People in the Right Positions at the Right Time. Hosp Pharm (SAGE Publications Sage CA: Los Angeles, CA) 48, no. 3 (2013).

Gallagher, Shaun. Self reference and schizophrenia. Exploring the self (John Benjamins Amsterdam, 2000).

Gray, Doug. Succession planning 101. Professional Safety (American Society of Safety Engineers) 59, no. 3 (2014).

Hirsh, W. Succession Planning Demystified. Brighton: The institute of Employment Studies, 2000.

Iheriohanma, EBJ. The Challenges of Globalization and Poverty in the Third World: A Sociological Discourse of Nigeria's Situation. The Third World in Sociological Perspective. Okigwe: FERP-FASMEN, 2008.

Iqbal, Sobia, and Ammad Zafar. Determinant of Frequent Road Accidents in Megacities (A Case Study of Karachi). Developing Country Studies 7, no. 3 (2017).

Ivanchevich, J.M. Human Resource Management. Irwin Professional Publication, 2007. 
Kim, Tae Kyun. T test as a parametric statistic. Korean Journal of Anesthesiology 68, no. 6 (2015).

Leibman, Michael, Ruth A Bruer, and Bill R Maki. Succession management: The next generation of succession planning. People and Strategy (Human Resource Planning Society) 19, no. 3 (1996).

Lowan, Vongani, and Clever Chisoro. The impact of Succession Planning for Business Survival: A case of Kwalita Business Consultants, Johannesburg (South Africa). Kuwait Chapter of Arabian Journal of Business and Management Review 5, no. 12 (2016).

Mathis, R.L., and J.H. Jackson. Human Resource Management. 11th. South-Western College Publication, 2006.

Odhiambo, J. O., L. Njanja, and C. Zakayo. Effects of succession planning practices on organization performance among the non-governmental organizations in Kenya. European Journal of Business Management 2, no. 1 (2014).

Park, Hyeoun-Ae. An Introduction to Logistic Regression: From Basic Concepts to Interpretation with Particular Attention to Nursing Domain. Journal of Korean Academy of Nursing 43, no. 2 (2013).

Rothwell, William J. Next generation talent management. HRM Review 8, no. 10 (2008).

Spurk, D, and AE Abele. Who earns more and why? A multiple mediation model from personality to salary. Journal of Business \& Psychology 26, no. 2 (2011).

Ugoni, Antony, and Bruce F Walker. The Chi square test: an introduction. Comsig review 4 , no. 3 (1999).

Wokoma, Chiemela U, and E.B.J Iheriohanma. Interation Between Globalization and Organizational Performance in the Third World: Nigeria in Focus.Studies in Sociology of Science 1, no. 2 (2010).

Zafar, Ammad, Aqil Memon, and Muhammad Nasir Khan. Implication of HR components on Employee Performance: A comparative analysis of Public \& Private Sector employees. Pakistan Administrative Review 2, no. 2 (2018). 